\title{
Mereological concepts for modelling parthood relations between אלהים and natural phenomena in the Hebrew Bible
}

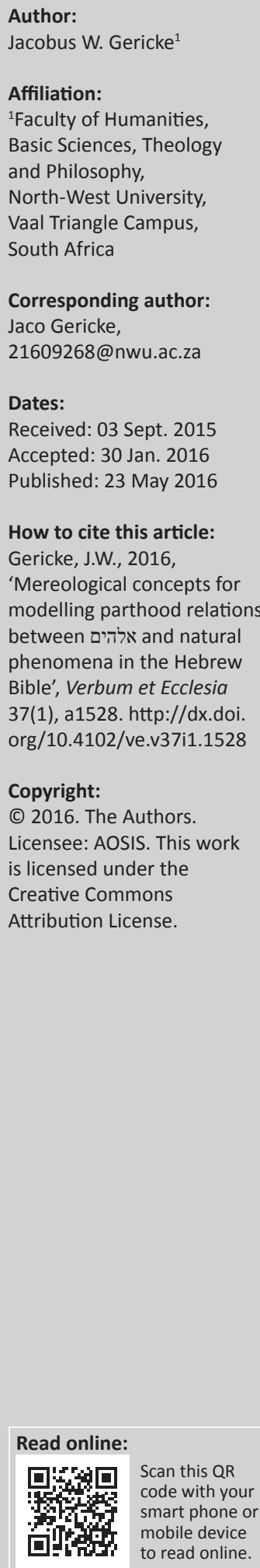

\begin{abstract}
In the Hebrew Bible, some texts represent what we would call 'natural' phenomena as being in some way related to entities classed to be אלהים in some sense of the Hebrew term; that is, God, gods, divine, deity, etc. Although various perspectives on these relations already exist in the available research on the topic, no philosophical approach to the data has of yet been conceived. In order to facilitate the latter, this study brackets the question as to what the relations between אלהים and natural phenomena in any given biblical context actually were. Yet its contribution lies in the way it aims to offer an introductory overview of some of the potentially relevant core concepts in mereology (parthood theory in metaphysics) that may be of aid in any future attempt at modelling such relations, however they were conceived.

Intradisciplinary and/or interdisciplinary implications: This article challenges the tradition of non-philosophical discourse in Old Testament theology, particularly with reference to the relational properties of Yhwh vis-a-vis natural phenomena. Its meta-theoretical application of concepts in formal descriptive mereological analysis represents an interdisciplinary supplementation of current ways of modelling God/World in the text.
\end{abstract}

\section{Introduction}

In Hebrew Bible (HB) studies, there are generally three views of the relation between אלהים proper and natural phenomena:

a) Minimal identification, for example: אלהים did not live in the processes of nature but instead controlled them (cf. Kaufmann 1972:70).

b) Medium identification, for example: אלהים was only at an early stage partly identified with certain natural phenomena (cf. Eichrodt 1967:262).

c) Maximal identification, for example: the term wלהים was, in a sense, the ancient Israelite concept for what we call 'Nature' (cf. Robinson 1946:1).

With regard to (a), one may say that it represents an absolute dichotomy between a natural and a supernatural order of things. This is despite the fact that the HB has no reference to a realm of אלהים wholly outside of the cosmos ('heaven' is not another dimension). As for (b), a supernatural state of affairs is still put in opposition to nature, yet following the emergence of more proper perspectives, natural phenomena came to be associated mostly with pagan אלהים or with signs of divine revelation. In (c) the natural/supernatural distinction in relation to אלהים collapses, with what it meant being reduced to the natural word.

\section{Some examples of close relations between אלהים and natural phenomena in the Hebrew Bible}

The HB's conceptualisations of the relation between things called אלהים to natural phenomena are complex and variable. This is already evidenced by a synchronic approach listing only a few instances of texts assuming a link between entities associated with the extension of אלהים (as both proper name and common noun) and what we would call 'natural phenomena':

- ... אלהים wind was moving over the face of the waters (Gn 1:2)

- I set my bow in the cloud, and it shall be a sign of the covenant between me and the earth (Gn 9:13)

- .... אלהים called to him out of the bush ... (Ex 3:4)

Note: This article is partially based on the 'Mereology' article published in the 'Stanford Encyclopedia of Philosophy', published 13 May 2003; substantive revision 13 February 2016, available here: http://171.67.193.20/entries/mereology/ 
- and the magicians said to Pharaoh, 'This is the finger of אלהים (Ex 8:19)

- at the blast of your nostrils the waters piled up (Ex 15:8)

- smoke went up from his nostrils, and devouring fire from his mouth; glowing coals flamed forth from him (2 Sm 22:9)

- before me no אלהים was formed, nor shall there be any after me (Is 43:10c)

- your righteousness is like the אל mountains (Ps 36:6)

- deep calls to deep at the thunder of your waterspouts; all your waves and your billows have gone over me (Ps 42:7)

- the nations rage, the kingdoms totter; he utters his voice, the earth melts (Ps 46:6)

- you visit the earth and water it, you enrich it; the אלהים river is full of water (Ps 65:5)

- the mountains were covered with its shade, the אל cedars with its branches (Ps 80:10)

- who cover yourself with light as with a garment (Ps 104:2a)

- as long as my breath is in me, and the spirit of אלוה is in my nostrils (Job 27:3)

- after it his voice roars; he thunders with his majestic voice, and he does not restrain the lightning when his voice is heard (Job 37:4)

- then Yhwh answered Job out of the whirlwind (Job 38:1)

- when the morning stars sang together, and all the sons of אלוה shouted for joy? (Job 38:7).

Of course, various translation possibilities exist in those examples where אלהים or its parallels are taken to function as adjectives (as opposed to, say, a noun as part of a genitive construction). Yet these renderings are not outlandish and actually represent standard fare in scholarly literature (as opposed to what is encountered in many popular translations of the Bible). Whatever we assume on this matter, interpretative intricacies aside, it should be evident that all of these texts assume there to be some or other relation between parts of something אלהים-like and what we would call a natural phenomenon. The latter includes the rainbow, natural disasters, wind, water, fire, air, the sea, trees, mountains, stars, et cetera. And yet this list reconstructed from the quoted texts above is not nearly complete (additional natural phenomena were also thus related).

However, the HB is not uniform in equating such natural phenomena with parts of אלהים. Although there are many other texts that express these same or similar ideas, one will also encounter examples of texts that present these same (natural) phenomena as quite apart from - or even opposed to - אלהים in the HB. Some cases in point would be sea, the stars, or the wind.

What exactly the relations between the אלהים and natural phenomena in the HB could be (there is no Biblical Hebrew term directly equivalent to our concept of 'nature') and what the individual texts quoted might mean with reference to this topic are bracketed for the present. Thus the question regarding the constitutive role of genre and context, the possible sense involving the use of implied metaphor and anthropomorphism, as well as the alternative possible ways of translating the texts above, do not concern us here. Not because these are not important or decisive - they are very much so - but because the interest of this study lies elsewhere; that is, with meta-theoretical matters that can function independently of whatever one assumes on these issues.

In the discussion to follow this article aims only to offer an overview of what a (analytic) philosophical approach to relations between parts of אלהים and natural phenomena might provide a descriptive meta-language aimed at clarifying data which itself is not always so forthcoming. No such point of view currently exists in scholarly research on אלהים in relation to natural phenomena in the $\mathrm{HB}$.

\section{An overview of mereological concepts for modelling metaphysical relations}

In this section basic concepts from theories of parthood relations in metaphysics will be introduced with reference to אלהים or others) vis-à-vis natural phenomena. This will comprise of an overview of various mereological axioms which might potentially offer a useful manner of stating in philosophical language what is implicit in a given text of the HB. As such it can be seen as putting forward a prolegomenon for any future research involving more indepth and specialised application and exegesis of the texts alluded to.

The outline below represents an adoption, adaptation, and reapplication of the introduction to mereology provided by Varzi (2015:n.p.). The latter is an example of a metatheoretical discussion that can be used to allow the biblical scholar to model what is understood as being the HB's own presuppositions pertaining to the parthood relations of and of natural phenomena as parts of אלהים as a whole and of natural phenomena as parts of parts of אלהים. This study is itself but a meta-theoretical introduction that is only meant to give a taste of the issues of interest in what remains a gap in the research.

To start with, consider the following generic instances of references to parts and wholes involving both things associated with the things called אלהים and natural phenomena (all alluding to motifs in the HB itself, without further specification of the context):

a) The breath of an אלהים is part an being.

b) The deified dead are part of the world of the אלהים

c) The heavens are the אלהים's part of the cosmos.

d) The stars are part of the אלהים's realm.

e) The glory of אלהים is part of what an אלהים is

f) A sacred space is part of an אלהים's abode.

g) The outermost edges of the earth are part of the אלהים's domain.

h) The first act was the creative part of אלהים-nature relations. 
All of these uses illustrate the general notion of 'part' in relation to אלהים that might become the main concern of a mereology of אלהים in the HB (cf. Gerstl \& Pribbenow 1995:865-889; Iris et al. 1988:261-288; Pribbenow 2002:35-50; Simons 2013:151-163; Westerhoff 2004:375-393; Winston, Chaffin \& Herrmann 1987:417-444). Basically, in popular English the concept of a 'part' can refer to any portion of a given אלהים entity. The portion may itself be attached to the remainder of an אלהים, as in (a) above, or detached from an אלהים, as in (b); it may be cognitively or functionally salient in אלהים, as in (a)-(b), or arbitrarily demarcated from אלהים, as in (c); אלהים אלה, as in (a)-(c), or disconnected from an אלהים, as in (d); homogeneous or otherwise wellmatched with אלהים, as in (a)-(d), material to אלהים, as in (a)-(e), or immaterial, as in (f); extended in אלהים, as in (a)-(f), or unextended, as in (g); spatial in relation to אלהים, as in (a)-(g), or temporal, as in (h); and so on (see Varsi 2015:n.p.).

Alternatively, as Varzi (2015:n.p.) implies, one may also use the term 'part' in relation to אלהים in a more limited manner, particularly within the context of the HB's god-talk. For instance, it can be used to designate only the cognitively salient relation of parthood illustrated in אלהים in (a), the relevant notion of salience in a אלהים's appearance being determined by Gestalt factors (cf. Bower and Glass 1976:456466; Palmer 1977:441-474; Rescher \& Oppenheim 1955:89106) or other perceptual and cognitive factors in interaction with אלהים at large (Tversky 2005:3-16). Or it may designate only the functional relation reflected in the אלהים parts list, as in (b), in which case the parts of אלהים are just its 'components', that is, those parts of אלהים that are available as individual units regardless of their actual interaction with the other parts of אלהים (A component is a part of an object, rather than just part of it; see e.g. Simons \& Dement 1996:255-276; Tversky 1989:983-995).

Clearly, Varzi's (2015:n.p.) outline of the properties of such restricted relations in אלהים may not coincide with those of parthood understood more broadly. A pure mereology is only concerned with the latter. However, the English word 'part' with reference to אלהים is sometimes also used in a broader sense:

(i) The thunder is part of Theice.

(j) Sound is part of an אלהים 's action.

(k) The holy mountain is part of אלהים's presence.

From Varzi (2015:n.p.)'s introduction above it is clear that references to natural phenomena as 'part' of אלהים can also be taken to designate the relation of material constitution, as in (i), or the relation of mixture composition in אלהים, as in (j), or the relation of group membership in the אלהים , as in (k). The mereological status of these relations between אלהים and natural phenomena, however, can be philosophically controversial. For instance, although the constitution relation of אלהים exemplified in (i) was included by Aristotle in his threefold taxonomy of parthood (Metaphysics, $\Delta, 1023 \mathrm{~b}$ ), many contemporary authors would rather construe it as a sui generis, non-mereological relation (see e.g. Baker 1997:599-621; Evnine
2011:212-235; Rea 1995:525-552; Wiggins 1980) or else as the relation of identity (Noonan 1993:133-146; Pickel 2010:193211), possibly contingent or occasional identity (Gallois 1998; Gibbard 1975:187-221; Robinson 1982:317-322).

Similarly, Varzi (2015:n.p.) implies that the ingredient-mixture relationship of a natural phenomenon with אלהים exemplified in (j) is of dubious mereological status, as the constituents thereof may undergo significant transformations that alter the structural characteristics they have in isolation from אלהים (cf. Bogen 1995:370-404; Fine 1995:266-369; Needham 2007:26-52; Sharvy 1983:227-239). His overview also suggests that for cases such as $(\mathrm{k})$, there might be disagreement concerning whether something else like the sons of the אלהים or the council of אלהים should be regarded as genuine mereological wholes (see Varzi 2015:n.p.) Some philosophers might think so (cf. Copp 1984:249; Martin 1988; Oppenheim \& Putnam 1958:3-36; Quinton 1976:1-27; Sheehy 2006:131-148), whereas others would be inclined to regard groups of אלהים as entities of a different sort and to construe the relation of group membership for the אלהים as distinct from parthood in relation to אלהים entities (see e.g. Effingham 2010:251-267; Gilbert 1989; Meixner 1997; Ritchie 2013:257-272; Ruben 1983:219-238; Simons 1980:483-486; Uzquiano 2004:135-153).

For all these reasons, one can concur with Varzi (2015:n.p.) in taking a mereology of אלהים in the HB to be concerned mainly with the principles governing the relations of natural phenomena with אלהים exemplified in (a)-(h), leaving it open whether one or more such broader uses of 'parts' of may themselves be subjected to mereological treatments of some sort. Also, it is worth stressing that a mereology of אלהים and natural phenomena based on Varzi's (2015:n.p.) scheme assumes no ontological restriction on the field of 'part'. In principle, the relata can be as different as material bodies of אלהים, אלהים אלה , אלים, ovents involving spatio-temporal regions containing אלהים, as in (a)-(h), as well as abstract entities such as properties of אלהים, אלהים propositions concerning אלהים, types or kinds of אלהים, such as found in the following examples:

(1) An אלהים is part of reality.

(m) Immortality is a part of many אלהים s' properties.

(n) The lightning and rainbow are part of אלהים as warrior's weaponry.

(o) Light is part of some אלהים s' matter.

Thus, at least according to Varzi's (2015:n.p.) outline, irrespective of how one feels about matters of ontology, if 'part' stands for the general relation between אלהים and natural phenomena exemplified by (a)-(h) above, and perhaps also (a)-(o), then it stands for a partial ordering - a reflexive, transitive, antisymmetric relation:

(p) Everything about an אלהים is part of itself.

(q) Any part of any part of an אלהים is itself part of that thing.

(r) Two totally distinct אלהים cannot be part of each other.

As Varzi (2015:n.p.) goes on to note, most theories put forward in the philosophical literature would accept (p)-(r). 
At this point it might be useful to introduce some degree of formalisation of possible אלהים-natural phenomena relations. Varzi (2015:n.p.) implies that this would help avoid ambiguities stemming from ordinary language and could facilitate comparisons and developments. For definiteness, I follow Varzi (2015:n.p.) in assuming here a standard firstorder language with identity, supplied with a distinguished binary predicate constant, ' $\mathrm{P}$ ', to be interpreted as the parthood relation. In addition, let $n$ stand for 'natural phenomenon' and אלהים (whether God, a god, gods, divinity, deity, etc.) so that $\mathrm{P} n \aleph$ reads thus: a natural phenomenon is a property of אלהים The rest of the symbols and operators will have their usual denotation (with the variable $\mathrm{Y}$ denoting Yhwh).

Taking the underlying logic to be the classical predicate calculus with identity, the requisites on parthood involving אלהים and natural phenomena discussed may then be regarded as forming a first-order theory characterised by the following proper axioms for ' $\mathrm{P}$ ':

\section{(P.a) Reflexivity Pnn \\ (P.b) Transitivity $(\mathrm{P} n \times \wedge \mathrm{P} \times \mathrm{Y}) \rightarrow \mathrm{P} n \mathrm{Y}$ \\ (P.c) Antisymmetry $(\mathrm{P} n \aleph \wedge \operatorname{P} n n) \rightarrow n=\kappa$.}

Given (P.a)-(P.c), a number of additional mereological predicates featuring אלהים and natural phenomena can be introduced in the form of definitions (cf. Varzi 2015:n.p.). For example:

$$
\begin{aligned}
& \text { (s) Equality } \\
& \mathrm{EQ} n \kappa={ }_{\mathrm{df}} \mathrm{P} n \boldsymbol{P} \wedge \mathrm{P} n \\
& \text { (t) Proper Parthood } \\
& \mathrm{PP} n \aleph={ }_{\mathrm{df}} \mathrm{P} n \aleph \wedge \neg n=\mathrm{\aleph} \\
& \text { (u) Proper Extension } \\
& \mathrm{PE} n \aleph={ }_{\mathrm{df}} \operatorname{P\aleph } n \wedge \neg n=\aleph \\
& \text { (v) Overlap } \\
& \mathrm{O} n \boldsymbol{\aleph}={ }_{\mathrm{df}} \exists n(\mathrm{PY} n \wedge \mathrm{PY} \times) \\
& \text { (w) Underlap } \\
& \mathrm{U} n \times{ }_{\mathrm{df}} \exists n(\mathrm{P} n \mathrm{Y} \wedge \mathrm{P} \times \mathrm{Y}) .
\end{aligned}
$$

The following biconditional, Varzi (2015:n.p.) notes, is also a straightforward consequence of the axioms (specifically, of P.a): (x) $\mathrm{P} n \ltimes \leftrightarrow(\mathrm{PP} n \ltimes \vee n=\aleph)$

From Varzi's (2015:n.p.) adapted introduction reapplied above it should now be obvious that one could in fact use proper parthood as an alternative starting point for the אלהים development of a classical mereology of the relations of and natural phenomena as parts of אלהים, using the righthand side of $(\mathrm{x})$ as a definiens for ' $\mathrm{P}$ '. This is, for instance, the option followed in Simons (1987), as also in Leśniewski's original theory (1916:169-173), where the partial ordering axioms for ' $\mathrm{P}$ ' are replaced by the strict ordering axioms for

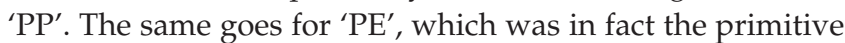
relation in Whitehead's (1919) semi-formal treatment of the mereology of events (and which is just the converse of ' $\mathrm{PP}^{\prime}$ ).
Other options are in principle possible, too. For example, Goodman (1951) used 'O' as a primitive and Leonard and Goodman (1940:45-55) used its opposite:

$$
\begin{aligned}
& \text { (y) Disjointness } \\
& \text { Dn }{ }={ }_{\mathrm{df}} \neg \mathrm{O} \mathrm{N} .
\end{aligned}
$$

Finally, we may note with Varzi (2015:n.p.) that the identity of אלהים and natural phenomena could itself be introduced by definition, because of the following obvious consequence of the antisymmetry postulate (P.c):

(z) $n=\mathrm{N} \leftrightarrow \mathrm{EQ} n \mathrm{~N}$.

Thus following the suggestion by Varzi (2015:n.p.), a theory can now be formulated in a pure first-order language by assuming (P.a) and (P.b) and replacing (P.c) with the following variant of the Leibniz axiom schema for identity (where $\varphi$ is any formula in the language):

(P.c') Indiscernibility

$$
\mathrm{EQ} n \aleph \rightarrow(\varphi n \leftrightarrow \varphi \aleph) .
$$

With Varzi (2015:n.p.), one may thus concur and argue that the parthood relation for אלהים and natural phenomena is in some sense conceptually prior to the identity relation (as in Sharvy 1983:234). And because 'EQ' is not definable in terms of 'PP' or 'PE' for אלהים and natural phenomena alone, except in the presence of stronger axioms, the argument would also provide evidence in favour of ' $\mathrm{P}$ ' as the most fundamental primitive. However, in some treatments 'PP' of אלהים and natural phenomena may be defined directly in terms of ' $\mathrm{P}$ ', without using identity, as per the following variant of $(\mathrm{t})$ :

(t') (Strict) Proper Parthood of אלהים

$$
\mathrm{PP} n \kappa={ }_{\mathrm{df}} \mathrm{P} n \aleph \wedge \neg \mathrm{P} n \text {. }
$$

(See e.g. Casati \& Varzi 1999:36; Eberle 1967:272; Goodman 1951:35; Niebergall 2011:274; Simons 1991:286). The concepts from Varzi (2015:n.p.) examined so far all assume that parthood in the relations between אלהים and natural phenomena is a perfectly determinate relation: given any two entities $n$ and $\mathrm{s}$, there is always an objective, determinate fact of the matter as to whether or not $n$ is part of $\mathrm{x}$. However, in some cases, even Varzi (2015:n.p.) admits that such is problematic. Perhaps there is no room for indeterminacy in the idealised mereology of space and time in the $\mathrm{HB}$ as such; but when it comes to the mereology of ordinary spatio-temporal particulars (for instance) the picture looks different. Think of objects such as the wind, light, clouds, and rocks. What exactly were their constitutive parts that were related to אלהים assumed to be? What were the mereological boundaries of the heavens, of the underworld, of a sacred space assumed to involve? Surely some things were held to be positively part of Mount Sinai/ Zion and some things were believed as being positively not part of it, yet there might be borderline things whose mereological relationship to Sinai/Zion and therefore to אלהים seem indeterminate.

Even the אלהים may, on closer look, give rise to indeterminacy issues. Surely Yhwh אלהים's body comprises his feet and 
surely it does not comprise the king as אלהים (cf. Ps 45:6). But what about thunder to come? It will be a firm part of the voice of אלהים, but soon thereafter disappear for good. Meanwhile, its mereological relation thereof to אלהים seems dubious. And what goes for material bodies of אלהים goes also for natural phenomena in relation thereto. For example, what were assumed to be the mereological boundaries of the divine council, angels, and spirits? What about the supposed boundaries of events such as theophanies, dreams and visions, verbal auditions and divine blessings or curses? Or what about the extensions of these regardless of how we talk about it? For example, the statement:

(aa) The word of an אלהים is part of that אלהים

may owe its indeterminacy to the semantic indeterminacy of 'אלהים': the HB's linguistic practices do not, on closer look, specify exactly which portion of reality is currently picked out by that word. In particular, in Varzi's (2015:n.p.) scheme they do not specify whether the name picks out something whose current parts of אלהים include the air of the voice that is coming and, as a consequence, the truth conditions of (aa) are not fully determined. But this is not to say that the particulars pertaining to the relations between אלהים and natural phenomena in the world of the text are mereologically indeterminate. Each one of a large variety of slightly distinct chunks of either אלהים or natural phenomena has an equal claim to being the referent of the vaguely introduced name 'אלהים', and each such thing has a perfectly precise mereological structure (Proponents of this view, which also affords a way of dealing with the so-called 'problem of the many', are Geach 1980; Heller 1990; Hughes 1986:213-233; Lewis 1993:23-38; McGee 1997:141-195; Unger 1980:411-467; Varzi 2001:49-65).

Alternatively, one could, as Varzi (2015:n.p.) implies hold that indeterminacy concerning אלהים and natural phenomena is due, not to the semantic indeterminacy of 'אלהים', but to that of a 'natural' phenomenon as 'part' of אלהים (as in Donnelly 2014:43-65). That is, there is no one parthood relation for אלהים and natural phenomena; rather, several slightly different relations are equally eligible as extension of the parthood predicates. And although some such relations connect the natural phenomenon to the אלהים, others do not. Either way, it is apparent that, on a de dicto understanding, mereological indeterminacy of the relations between אלהים and natural phenomena need not be due to the way the world in the text is (or isn't): it may just be an instance of a more general and widespread phenomenon of indeterminacy that affects our language and our conceptual apparatus at large. The principles of mereology, understood as a theory of the parthood relation, or of all the relations of אלהים and natural phenomena that qualify as admissible interpretations of the parthood predicate, would hold regardless.

By contrast, in the second way of understanding, indeterminacy for relations between אלהים and natural phenomena is genuinely de re: there is no objective fact of the matter as to whether a natural phenomenon is part of אלהים, regardless of the words we use to describe the situation. For example, in this view a relation would be indeterminate, not because of the vagueness of the word 'אלהים', but because of the vagueness of the thing that an אלהים was assumed to be itself: there simply would be no fact of the matter as to whether the natural phenomenon is part of אלהים. As it turns out, this is not a popular view: already Russell (1923) argued that the very idea of worldly indeterminacy betrays a 'fallacy of verbalism', and some have gone as far as saying that de re indeterminacy is simply not 'intelligible' (Dummett 1975:314; Lewis 1986:212) or ruled out a priori (Jackson 2001:657).

A next question which might now arise is whether an with indeterminate parts has indeterminate identity? Following Evans (1978:208), many philosophers have taken the answer to be obviously in the affirmative. Others, such as Cook (1986:179-186), Sainsbury (1989:99-103), or Tye (2000:195-209), hold what would be the opposite view: vague אלהים objects are mereologically elusive, but they have the same precise identity conditions as any other object. Still others maintain that the answer depends on the strength of the underlying mereology.

A related question is: Does countenancing אלהים objects with indeterminate parts entail that composition of the relations between אלהים and natural phenomena be vague, that is, that there is sometimes no matter of fact whether some things make up a whole? A popular view, much influenced by Lewis (1986:212), suggests it does. Others, such as Morreau (2002:338) might argue instead that the link between vague parthood in אלהים and natural phenomena and vague composition of and natural phenomena is unwarranted: perhaps the de re indeterminacy is inherited by some instances of:

(bb) אלהים is composed of $x$ and the light.

(for example, $x$ could be something that is just like אלהים except that the light is determinately not part of it); yet this would not amount to saying that composition between the אלהים and the natural phenomenon is vague, for the following might nonetheless be true:

(cc) There is something composed of $x$ and the light.

Of course, as Varzi's (2015:n.p.) article implies, there is the general question of how one should handle logically complex statements concerning, at least in part, אלהים and natural phenomena in texts where they might be represented as mereologically indeterminate objects. A natural choice might be to rely on a three-valued semantics of some sort, the third value being, strictly speaking, not a truth value but rather a truth-value gap. Here one might bring to bear the truth-tables of Kleene (1938:150-155) or those of Łukasiewicz (1920:169-171), or even non-truth-functional accounts (e.g. the supervaluationism of Akiba 2000:359-370 and Morreau 2002:331-361). Fine (1975:265-300) suggested the latter as a theory for dealing with de dicto indeterminacy, the idea being that a statement within the meta-language involving vague expressions about אלהים and natural phenomena should count as true (false) if and only it is true (false) on every 'precisification' of those expressions. 
Still, in favour of what Varzi (2015:n.p.) implies, de re indeterminacy regarding אלהים may exploit the same idea by speaking instead of precisifications of the underlying reality - what Sainsbury (1989:99-103) calls 'approximants', Cohn and Gotts (1996:171-187) 'crispings', and Parsons (2000) 'resolutions' of אלהים and natural phenomena as vague objects. As a result, one would be able to explain why, for example, (dd) below appears to be true and (ee) false (assuming that אלהים 's breath was definitely assumed to be part of אלהים), whereas both conditionals would be equally indeterminate on Kleene's semantics and equally true on Łukasiewicz's:

(dd) If the thunder is part of the breath and the breath is part of אלהים, then the thunder itself is part of אלהים.

(ee) If the thunder is part of the breath and the breath is part of אלהים, then the thunder itself is not part of אלהים. - -

As for option (ee) - to the extent that what Varzi's (2015:n.p.) outline suggests is de re mereological indeterminacy in אלהים and natural phenomena as a matter of degree - the picture is different. Here the main motivation is that whether or not a natural phenomenon is part of אלהים is really not an all-ornothing affair. Some natural phenomena might not have been assumed to be a definite part of אלהים, even as it originates from the deity. Also, some natural phenomena could have been assumed to be part of אלהים to a lesser degree than others, and the postulates of a mereological approach to the relation between אלהים and natural phenomena in the HB should be sensitive to such distinctions (cf. Varzi 2015:n.p.)

\section{Conclusion}

The reader not familiar with Varzi's (2015:n.p.) introduction to philosophical mereology might wonder what on earth this seemingly strange conceptual framework could possibly help the biblical exegete with. As meta-theoretical reflection, this study can be seen as a prolegomenon to a philosophical approach adapted for the modelling of parthood relations between אלהים entities and natural phenomena in the worlds of the text. Such an approach has yet to be refined. The aim was not to supplant traditional research or engage the text directly but to provide a metaphysical framework with which mereological analysis of the HB's own assumptions on the related issues can be mapped. Whether or not it succeeds depends on the ability of the exegete using the method, for the meta-language with all its technical terms and formality is no more distortive of or irrelevant to making sense of the textual data than any other jargon in HB scholarship seeking to reconstruct textual propositions regarding the relations between אלהים entities and natural phenomena.

To be sure, the HB itself never asks these questions or speaks in this language. Yet it does not follow that mereological analysis is in any way illegitimate. For the HB refrains from spelling out parthood relations, not because the texts did not have mereological assumptions, but because it took the mereological notions it operated with for granted. Their presence is itself presupposed for the very possibility of structuring nascent relations between the אלהים entities and what we call natural phenomena. Because the conceptual background of the readers and the worlds of the text do not overlap, reconstructions of these mereological assumptions will allow us to 'see' what is implicit in the texts themselves - in new ways - presuppositions which we otherwise would not even be aware of. And although different texts presuppose different relations and many may not be very forthcoming, mereological perspectives represent a gap in the research that remains to be filled. For it is one thing to describe the said relations in theological terms. It is quite another to reconstruct the metaphysical assumptions that make it all possible.

\section{Acknowledgements Competing interests}

The author declares that he has no financial or personal relationships which may have inappropriately influenced him in writing this article.

\section{References}

Akiba, K., 2000, 'Vagueness as a modality', Philosophical Quarterly 50, 359-370.

Baker, L.R., 1997, 'Why constitution is not identity', Journal of Philosophy 94, 599-621.

Bogen, J., 1995, 'Fire in the belly: Aristotelian elements, organisms, and chemical compounds', Pacific Philosophical Quarterly 76, 370-404.

Bower, G.H. \& Glass, A., 1976, 'Structural units and the reintegrative power of picture fragments', Journal of Experimental Psychology: Human Learning and Memory 2, $456-466$.

Casati, R. \& Varzi, A.C., 1999, Parts and places: The structures of spatial representation, MIT Press, Cambridge, MA.

Cohn, A.G. \& Gotts, N., 1996, "The "egg-yolk" representation of regions with indeterminate boundaries', in P. Burrough and A. Frank (eds.), Geographical objects with undetermined boundaries, pp. 171-187, Taylor and Francis, London.

Cook, M., 1986, 'Indeterminacy of identity', Analysis 46, 179-186.

Copp, D., 1984, 'What collectives are: Agency, individualism and legal theory', Dialogue 23, 249-269.

Donnelly, M., 2014, 'A linguistic account of mereological vagueness', in K. Akiba and A. Abasnezhad (eds.), Vague objects and vague identity. New essays on ontic vagueness, pp. 43-65, Springer, Berlin.

Dummett, M., 1975, 'Wang's paradox', Synthese 30, 265-300.

Eberle, R.A., 1967, 'Some complete calculi of individuals', Notre Dame Journal of Formal Logic 8, 267-278.

Effingham, N., 2010, 'The metaphysics of groups', Philosophical Studies 149, 251-267. Eichrodt, W., 1967, Old Testament theology, vol. 2, transl. E Green, SCM Press, London. Evans, G., 1978, 'Can there be vague objects?', Analysis 38, 208.

Evnine, S., 2011, 'Constitution and composition: Three approaches to their relation', ProtoSociology 27, 212-235.

Fine, K., 1975, 'Vagueness, truth and logic', Synthese 30, 265-300.

Fine, K., 1995, 'The problem of mixture', Pacific Philosophical Quarterly 76, 266-369.

Gallois, A., 1998, Occasions of identity. The metaphysics of persistence, change, and sameness, Clarendon Press, Oxford.

Geach, P.T., 1980, Reference and generality, 3rd edn., Cornell University Press, Ithaca.

Gerstl, P. \& Pribbenow, S., 1995, 'Midwinters, end games, and bodyparts. A classification of part-whole relations', International Journal of Human-Computer Studies 43, 865-889.

Gibbard, A., 1975, 'Contingent identity', Journal of Philosophical Logic 4, 187-221.

Gilbert, M., 1989, On social reality, Princeton University Press, Princeton, NJ.

Goodman, N., 1951, The structure of appearance, Harvard University Press, Cambridge, MA. (3rd ed. Dordrecht: Reidel, 1977).

Heller, M., 1990, The ontology of physical objects: Four-dimensional hunks of matter Cambridge University Press, Cambridge.

Hughes, C., 1986, 'Is a thing just the sum of its parts?', Proceedings of the Aristotelian Society 86, 213-233.

Iris, M.A., Litowitz, B.E. \& Evens, M., 1988, 'Problems of the part-whole relation', in M. Evens (ed.), Relations models of the lexicon, pp. 261-288, Cambridge University Press, Cambridge. 
Jackson, F., 2001, 'Responses', Philosophy and Phenomenological Research 62, 653-664.

Kaufmann, Y., 1972, The history of Israelite religion: From its beginnings to the Babylonian exile, transl. M. Greenberg, University of Chicago Press, Chicago, IL.

Kleene, S.C., 1938, 'On a notation for ordinal numbers', Journal of Symbolic Logic 3 150-155.

Leonard, H.S. \& Goodman, N., 1940, 'The calculus of individuals and its uses', Journa of Symbolic Logic 5, 45-55.

Leśniewski, S., 1916, Podstawy ogólnej teoryi mnogości. I, Moskow: Prace Polskiego Koła Naukowego w Moskwie, Sekcya matematyczno-przyrodnicza; Eng. trans. by Koła Naukowego w Moskwie, Sekcya matematyczno-przyrodnicza; Eng. trans. by
D.I. Barnett, 1992, 'Foundations of the general theory of sets. I', in S. Leśniewski, S.J. Surma \& R. Barnett. (eds.), Collected works, vol. 1, pp. 129-173, Kluwer, S.J. Surma
Dordrecht.

Lewis, D.K., 1986, The plurality of worlds, Blackwell, Oxford.

Lewis, D.K., 1993, 'Many, but almost one', in J. Bacon, K. Campbell \& L. Reinhardt (eds.), Ontology, causality, and mind, pp. 23-38, Cambridge University Press, Cambridge.

Łukasiewicz, J., 1920, 'O logice trojwartosciowej', Ruch Filozoficny 5, 169-171; Eng. transl. S. McCall: 1967, 'On three-valued logic', in S. McCall (ed.), Polish logic 1920-1939, pp. 15-18, Oxford University Press, Oxford.

Martin, R.M., 1988, Metaphysical foundations: Mereology and metalogic, Philosophia, Munich.

McGee, V., 1997, 'Kilimanjaro', Canadian Journal of Philosophy (Supplement) 23 141-195.

Meixner, U., 1997, Axiomatic formal ontology, Kluwer, Dordrecht.

Morreau, M., 2002, 'What vague objects are like', Journal of Philosophy 99, 333-361.

Needham, P., 2007, 'Macroscopic Mixtures', Journal of Philosophy 104, 26-52.

Niebergall, K.-G., 2011, 'Mereology', in R. Pettigrew and L. Horsten (eds.), The continuum companion to philosophical logic, pp. 271-298, Continuum, London.

Noonan, H., 1993, 'Constitution is identity', Mind 102, 133-146.

Oppenheim, P. \& Putnam, H., 1958, 'Unity of science as a working hypothesis', Minnesota Studies in the Philosophy of Science 2, 3-36.

Palmer, S.E., 1977, 'Hierarchical structure in perceptual representation', Cognitive Psychology 9, 441-474

Parsons, T., 2000, Indeterminate identity. Metaphysics and semantics, Clarendon Press, Oxford.

Pickel, B., 2010, 'There is no 'is' of constitution', Philosophical Studies 147, 193-211.

Pribbenow, S., 2002, 'Meronymic relationships: From classical mereology to complex part-whole relations', in R. Green \& C.A. Bean (eds.), The semantics of relationships. An interdisciplinary perspective, pp. 35-50, Kluwer, Dordrecht.

Quinton, A., 1976, 'Social objects', Proceedings of the Aristotelian Society 76, 1-27.

Rea, M., 1995, 'The problem of material constitution', Philosophical Review 104 $525-552$.

Rescher, N. \& Oppenheim, P., 1955, 'Logical analysis of gestalt concepts', British Journal for the Philosophy of Science 6, 89-106.
Ritchie, K., 2013, 'What are groups?', Philosophical Studies 166, 257-272.

Robinson, H.W., 1946, Inspiration and revelation in the Old Testament, Oxford University Press, Oxford.

Robinson, D., 1982, 'Reidentifying matter', Philosophical Review 91, 317-342.

Ruben, D.-H., 1983, 'Social wholes and parts', Mind 92, 219-238.

Russell, B., 1923, 'Vagueness', Australasian Journal of Psychology and Philosophy 1, 84-92.

Sainsbury, R.M., 1989, 'What is a vague object', Analysis 49, 99-103.

Sharvy, R., 1983, 'Mixtures', Philosophy and Phenomenological Research 44, 227-239.

Sheehy, P., 2006, 'Sharing space. The synchronic identity of social groups', Philosophy of the Social Sciences 36, 131-148.

Simons, P.M. 1980, 'Individuals, groups and manifolds', in R. Haller and W. Grass (eds.), Logic, language and philosophy, pp. 483-486, Hölder-Pichler-Tempsky, Vienna.

Simons, P.M., 1987, Parts. A study in ontology, Clarendon Press, Oxford.

Simons, P.M., 1991, 'Free part-whole theory', in K. Lambert (ed.), Philosophical applications of free logic, pp. 285-306, Oxford University Press, Oxford.

Simons, P.M., 2013, 'Varieties of parthood: Ontology learns from engineering', in D.P. Michelfelder, D.E. Goldberg \& N. McCarthy.(eds.), Philosophy and engineering: Reflections on practice, principles and process, pp. 151-163, Springer, Berlin.

Simons, P.M. \& Dement, C.W., 1996, 'Aspects of the mereology of artifacts', in R. Poli and P.M. Simons (eds.), Formal ontology, pp. 255-276, Kluwer, Dordrecht.

Tversky, B., 1989, 'Parts, partonomies, and taxonomies', Developmental Psychology $25,983-995$.

Tversky, B., 2005, 'On exploring parts and wholes', in J.S. Gero and M.L. Maher (eds.), Computational and cognitive models of creative design VI. Preprints of the International Conference, pp. 3-16, Key Centre of Design Computing and Cognition, Sydney.

Tye, M., 2000, 'Vagueness and reality', Philosophical Topics 28, 195-209.

Unger, P., 1980, 'The problem of the many', Midwest Studies in Philosophy 5, 411-467.

Uzquiano, G., 2004, 'The Supreme Court and the Supreme Court justices: A metaphysical puzzle', Noûs 38, 135-153.

Varzi, A.C., 2001, 'Vagueness in geography', Philosophy and Geography 4, 49-65.

Varzi, A.C., 2015, 'Mereology', in E.N. Zalta (ed.), The Stanford encyclopedia of philosophy (Fall 2015 edn.), viewed 13 March 2015, from http://plato.stanford. edu/archives/fall2015/entries/mereology

Westerhoff, J., 2004, 'A taxonomy of composition operations', Logique and Analyse 47, 375-393.

Whitehead, A.N., 1919, An enquiry concerning the principles of natural knowledge, Cambridge University Press, Cambridge.

Wiggins, D., 1980, Sameness and substance, Blackwell, Oxford.

Winston, M., Chaffin, R. \& Herrmann, D., 1987, 'A taxonomy of part-whole relations', Cognitive Science 11, 417-444. 